\title{
Isolation and characterisation of putative adhesins from Helicobacter pylori with affinity for heparan sulphate proteoglycan
}

\author{
E. RUIZ-BUSTOS, J.L. OCHOA, T. WADSTRÖM* and F. ASCENCIO
}

Department of Marine Pathology, Center for Biological Research, La Paz, Baja California Sur, 23000 México and * University of Lund, Institute of Medical Microbiology, Sölvegatan 23, S-223 62 Lund, Sweden

\begin{abstract}
A pool of heparan sulphate-binding proteins (HSBPs) from Helicobacter pylori culture supernates was obtained by sequential ammonium sulphate precipitation and affinity chromatography on heparin-Sepharose. The chromatographic procedure yielded one major fraction that contained proteins with heparan sulphate affinity as revealed by inhibition studies of heparan sulphate binding to $\mathrm{H}$. pylori cells. Preparative iso-electric focusing, SDS-PAGE and blotting experiments, with peroxidase(POD)-labelled heparan sulphate as a probe, indicated the presence of two major extracellular proteins with POD-heparan sulphate affinity. One protein had a molecular mass of $66.2 \mathrm{kDa}$ and a pI of 5.4, whilst the second protein had a molecular mass of $71.5 \mathrm{kDa}$ and a pI of 5.0 . The N-terminal amino acid sequence of the 71.5-kDa HSBP did not show homology to any other heparin-binding protein, nor to known proteins of $\mathrm{H}$. pylori, whereas the 66.2-kDa HSBP showed a high homology to an Escherichia coli chaperon protein and equine haemoglobin. A third HSBP was isolated from an outer-membrane protein (OMP) fraction of $\mathrm{H}$. pylori cells with a molecular mass of $47.2 \mathrm{kDa}$. The amino acid sequence of an internal peptide of the OMP-HSBP did not show homology to the extracellular HSBP of $H$. pylori, or to another microbial HSBP.
\end{abstract}

\section{Introduction}

Helicobacter pylori is a micro-aerophilic gram-negative spiral-shaped bacterium that is considered as a prevalent human- and non-human-primate-specific pathogen [1-3]. It is a causative agent in chronic active gastritis, gastric and duodenal ulcers, and gastric adenocarcinoma [4]. $H$. pylori is known by its characteristic association with gastric mucus-secreting cells in vivo [5] and it has been found within and beneath the mucus layer and attached to the gastric epithelial cells [6].

Several studies have indicated that this micro-organism has unique cellular characteristics that allow it to colonise the human stomach mucosa. These characteristics include the high motility of the bacteria [7, 8], the profuse production of urease [9-11] and the expression of surface lectins that recognise specific

Received 29 March 2000; revised version received 10 July 2000; accepted 26 July 2000.

Corresponding author: Dr F. Ascencio (e-mail: ascencio@, cibnor.mx). stomach mucosa cell receptors [4, 12]. A cytotoxin has been described that causes lethal effects on various mammalian cells and gastric epithelial lesions [8, 1216]. $H$. pylori has an SOS regulon important in the repair of DNA damage caused by exposure to a low $\mathrm{pH}$ or reactive oxygen species produced by immune cells during bacterial infections [17].

Recently it was found that $H$. pylori binds with high affinity to the glycosaminoglycans such as heparin and heparan sulphate, and to heparin-dependent growth factors $[18,19]$. Proteoglycans are important in the normal development of cellular function, blood coagulation, extracellular matrix organisation, cell adhesion and cytokine action [20,21]. Yet, the distribution of various proteoglycans during human wound healing is poorly understood [22, 23].

The heparan sulphate (HS) proteoglycan participates as an adhesion molecule, binding extracellular matrix proteins (collagen, fibronectin and vitronectin) in interactions that can affect cell adhesion [24, 25]. Many organisms have been shown to use the extracellular matrix as a means of adhesion once the tissue is damaged. 
It has been reported that some pathogens, such as Streptococcus pyogenes, S. mutans and Staphylococcus aureus, bind heparan sulphate, which also acts as the cell receptor for members of the herpes virus group $[18,26]$.

Doig et al. suggested that $H$. pylori adhesion may be a multi-step process that begins with non-specific hydrophobic and electrostatic interactions, followed by a second step involving a much closer adherence process that may include adhesins and lectin interactions [27]. The adhesion process is further enhanced once an ulceration induced by the bacteria exposes the base membrane heparan sulphate, providing the pathogen with a more firm attachment.

It may be worthwhile to find out if bacterial proteins with affinity for proteoglycans, such as heparan sulphate, may be useful for the development of vaccination protocols. This study reports the purification and a partial biochemical characterisation of cellassociated and extracellular proteins from $H$. pylori with affinity for heparan sulphate proteoglycan.

\section{Materials and methods}

\section{Chemicals}

All chemicals of analytical grade were purchased from Sigma, unless otherwise stated. Heparin Hi-Trap column was purchased from Upjohn-Pharmacia, Uppsala, Sweden. Heparan sulphate (HS) purchased from Sigma (from swine gut mucosal tissue) was coupled to horseradish peroxidase (POD-HS) as follows. POD was incubated with $0.1 \mathrm{M}$ sodium periodate for $20 \mathrm{~min}$ at room temperature and dialysed overnight against $1 \mathrm{mM}$ sodium acetate $(\mathrm{pH} 4.4)$. HS $(1 \mathrm{mg} / \mathrm{ml})$ was mixed with the activated POD for $4 \mathrm{~h}$ at room temperature and the reaction was stopped by the addition of a sodium borohydride solution $(4 \mathrm{mg} / \mathrm{ml})$. Finally, glycerol was added at $50 \%$ and the mixture was stored at $-20^{\circ} \mathrm{C}$ in the dark until used.

\section{Bacterial strain and growth conditions}

H. pylori strain 25 (clinical isloate from adenocarcinoma) was provided by Professor T. Wadström (Lund University, Sweden). This strain, which has previously been examined for haemagglutinins [18] and was also found to bind HS with high affinity [28], was selected for characterisation of HSBPs.

H. pylori was grown on solid GAB-CAMP (GC) agar (BBL, Becton Dickinson, USA) supplemented with lysed human blood $\left(80^{\circ} \mathrm{C}, 20 \mathrm{~min}\right) 8.5 \%$, inactivated horse serum $\left(56^{\circ} \mathrm{C}, 30 \mathrm{~min}\right) 10 \%$, cysteine hydrochloride $0.05 \%$ and the following antibiotics: vancomycin $6 \mu \mathrm{g} / \mathrm{ml}$, nalidixic acid $(20 \mu \mathrm{g} / \mathrm{ml})$ and ketoconazole $3 \mu \mathrm{g} / \mathrm{ml}$ at $37^{\circ} \mathrm{C}$ for 3 days in micro-aerophilic conditions. The cells were then harvested and inocu- lated in two separate broth systems: (A) Brucella broth containing fetal calf serum $10 \%$ (BBFCS) and supplemented with antibiotics [29-32], and (B) a serum-free Brucella broth containing cyclodextrins (BBCD) and antibiotics [30,33]. The culture media were then incubated as above; cells were harvested and stored at $-20^{\circ} \mathrm{C}$ until used $[9,34]$. The culture supernates were used for further protein isolation.

\section{Protein fractionation}

The proteins were precipitated from the culture supernates with ammonium sulphate at $0-40,40-60,60-80$ and $80-100 \%$ saturation. The precipitated proteins in each fraction were centrifuged $\left(18000 \mathrm{~g}, 30 \mathrm{~min}, 5^{\circ} \mathrm{C}\right)$ and then resuspended in distilled water. The fractions were dialysed against four changes of $0.01 \mathrm{M}$ ammonium bicarbonate. The protein concentration in each fraction was determined with the BioRad (Richmond, CA, USA), protein dye reagent with bovine serum albumin (BSA) for the construction of a standard curve. All the protein fractions were stored at $-20^{\circ} \mathrm{C}$ until used.

\section{Affinity chromatography}

The protein fractions obtained from $60-80 \%$ ammonium sulphate precipitation of culture supernates of $H$. pylori cells were subjected to a modified heparin affinity-chromatography procedure [35]. Briefly, protein samples were filtered through a $0.45-\mu \mathrm{m}$ filter and diluted $1: 1$ with $0.1 \mathrm{M}$ sodium acetate $(\mathrm{pH}$ 5.0). One $\mathrm{ml}$ of diluted sample was applied to a 5-ml Heparin HiTrap column, previously equilibrated with $0.1 \mathrm{M}$ sodium acetate buffer ( $\mathrm{pH}$ 5.0). Proteins lacking affinity for heparin were washed through with $0.1 \mathrm{M}$ sodium acetate (pH 5.0) at a flow rate of $1 \mathrm{ml} / \mathrm{min}$. Adsorbed proteins were eluted with an $\mathrm{NaCl}$ gradient (0-2 M) over $30 \mathrm{~min}$ at the same flow rate and $1-\mathrm{ml}$ fractions were collected. Finally, the column was washed with $0.01 \mathrm{M} \mathrm{NaOH}$ and then regenerated with distilled water and $0.1 \mathrm{M}$ sodium acetate buffer. The fractions collected were dialysed extensively against $10 \mathrm{mM}$ ammonium bicarbonate and stored at $-20^{\circ} \mathrm{C}$ until used.

\section{Outer-membrane protein (OMP) extraction}

OMPs were obtained as described previously [36, 37]. Briefly, bacterial cells were harvested, washed and resuspended in $1 \mathrm{mM}$ TRIS-EDTA (pH 7.0) at a final concentration of $10^{6}$ cells $/ \mathrm{ml}$. Cells were disrupted by sonication $(10 \times 30 \mathrm{~s}$ at $25 \mathrm{~W}$ on ice $)$ and centrifuged $(7500 \mathrm{~g}, 20 \mathrm{~min})$ to remove cell debris. Total membranes were collected by centrifugation $(20000 \mathrm{~g}$, $90 \mathrm{~min}$ ) at $4^{\circ} \mathrm{C}$. The pellet was resuspended in $0.5 \mathrm{ml}$ of distilled water. Sodium lauroylsarcosine was added to give a final concentration of $2 \%$ at $\mathrm{pH} 7.5$ and the suspension was incubated at $37^{\circ} \mathrm{C}$ for $30 \mathrm{~min}$ with gentle shaking and then centrifuged $(20000 \mathrm{~g}, 90 \mathrm{~min})$ at $4^{\circ} \mathrm{C}$. The pellet was washed twice in $0.05 \mathrm{M}$ Tris, 
$\mathrm{pH} 7.5$, and suspended in distilled water. OMP extracts were then stored at $-20^{\circ} \mathrm{C}$ until used.

\section{$S D S-P A G E$}

The protein samples were electrophoresed according to the method of Laemmli [38] with the BioRad MiniProtean II system or the Protean apparatus (BioRad). Protein samples were denatured before electrophoresis for $7 \mathrm{~min}$ at $100^{\circ} \mathrm{C}$ in sample buffer $(0.6 \mathrm{M}$ Tris- $\mathrm{HCl}$, $\mathrm{pH} 6.8$, glycerol $10 \%$, SDS $10 \%, \beta$-mercaptoethanol $5 \%$ and bromophenol blue $0.05 \%$ ). Samples containing $5-10 \mu \mathrm{g}$ of total protein and molecular mass standard were loaded on to a discontinuous acrylamide gel (stacking gel 4\%, separating gel 12\%), electrophoresed at $80 \mathrm{~V}$ for $2 \mathrm{~h}$ and stained with Coomassie Blue.

\section{Blotting}

Proteins were electrophoresed in the BioRad SDSPAGE Mini-Protean II system and then transferred to Immobilon membranes (Millipore, Bedford, USA) by a semi-dry electroblotter at $190 \mathrm{~mA}$ for $2 \mathrm{~h}$. The lane of the molecular mass markers was cut and stained with Coomassie Blue. The membrane was blocked with BSA 3\% in saline phosphate buffer (PBS), washed with three 15-min changes of PBS-Tween $200.05 \%$ (PBS$\mathrm{T}$ ), followed by a wash with $0.1 \mathrm{M}$ sodium acetate, pH 5.0. POD-HS was added to the membrane and incubated for $90 \mathrm{~min}$, washed with three 20-min changes of sodium acetate buffer-Tween 20 and two 5-min changes of sodium acetate buffer. The membrane was developed with diaminobenzidine $2.5 \mathrm{mg}$ and $\mathrm{H}_{2} \mathrm{O}_{2} \quad 2.5 \mu \mathrm{l}$ in $10 \mathrm{ml}$ of $0.1 \mathrm{M}$ sodium acetate, $\mathrm{pH}$ 5.0. The reaction was stopped with $0.1 \mathrm{M}$ sodium metabisulphite.

\section{Preparative iso-electric focusing}

Protein samples were adjusted to a concentration of 5$10 \mu \mathrm{g} / \mathrm{ml}$ in sample buffer $(9.5 \mathrm{M}$ urea, Triton X-100 $2 \%$, ampholine 3-10 2\%, $50 \mathrm{~mm}$ dithiothreitol) before iso-electric focusing (IEF). The gel was prepared with acrylamide $5 \%$ and a $\mathrm{pH}$ range of 3-10 and placed in a horizontal electrophoretic chamber. The samples and $\mathrm{pI}$ standards (Pharmacia) were loaded on to the gel and electrophoresed at $500 \mathrm{~V}$ and $250 \mathrm{~mA}$ for $3 \mathrm{~h}$. The gel was stained with Coomassie Blue R-250 and pI measurements were calculated from a pI standard curve according to the migration distance of the $\mathrm{pI}$ standards. A second electrofocusing run was transferred to Immobilon membranes (Millipore) and developed with POD-HS as described above.

\section{$\mathrm{NH}_{2}$-terminal amino acid sequencing}

The proteins were electrophoresed with the Protean apparatus (BioRad) according to the protocol described above, transferred to Immobilon membranes (Millipore) and stained with Coomassie Blue. The HSBP bands were cut off, de-stained with methanol:acetic acid:distilled water (5:1:4) and thoroughly washed with distilled water. The amino acid analysis was performed on trypsin hydrolysates of these proteins with a yield of 10 amino acids from the $\mathrm{N}$-terminal chain. The analysis was done at the University of Arizona, Division of Biotechnology, under the supervision of Dr Wallace Clark.

\section{Results}

\section{Isolation of extracellular HSBP}

Electrophoretic profiles of culture supernates from both BBFCS and BBCD revealed that the $0-40 \%$ and $40-$ $60 \%$ ammonium sulphate precipitation fractions contained the highest composition and concentration of proteins (Fig. 1a). In both culture media, two bands were evident in the $40-60 \%$ fractions, one band at $66.2 \mathrm{kDa}$ and the second at $54.4 \mathrm{kDa}$, but 44.3-, 30.0and $11.3-\mathrm{kDa}$ protein bands could also be detected (the latter only in BBFCS).

In the $60-80 \%$ fraction of both culture media, two high molecular mass and one low molecular mass proteins were present at $71.5,66.2$ and $11.3 \mathrm{kDa}$. A few minor protein bands at 47.2 and $14.4 \mathrm{kDa}$ were also present in both culture media. At $80-100 \%$ saturation, no protein bands could be detected by SDS-PAGE in either medium.

Blotting studies with POD-HS as a probe showed the presence of two main protein bands with HS binding activity at 66.2 and $54.4 \mathrm{kDa}$ (Fig. 1b) in the $0-40$ and $40-60 \%$ fractions of both culture media. Also, a smear was observed in the range $20-31 \mathrm{kDa}$ in BBFCS. In $\mathrm{BBCD}$, two proteins with POD-HS affinity were detected at 47.2 and $30.0 \mathrm{kDa}$, and at $60-80 \%$ ammonium sulphate precipitation, three HSBPs were evident, again at 71.5, 66.2 and $54.4 \mathrm{kDa}$.

A comparative SDS-PAGE and blotting analysis of the BBFCS and BBCD cultures indicated that the proteins produced and secreted into the BBCD culture supernates were present in lower concentrations. However, both BBFCS and the BBCD supernates showed common protein bands (Fig. 1a), mainly in the molecular mass range $40-65 \mathrm{kDa}$. Some bands that were present in BBFCS were less evident in BBCD (Fig. 1a). These could be caused by the presence of fetal calf serum in the medium with proteins with similar molecular mass to those secreted by H. pylori. In either case, the three major HSBPs $(71.5,66.2$ and $54.4 \mathrm{kDa}$ ) were present in both culture media (Fig. 1b).

\section{Affinity chromatography}

The ammonium sulphate fractions were subjected to affinity chromatography (Fig. 2). SDS-PAGE analysis of the eluted proteins obtained from the Hi-Trap 
a

b

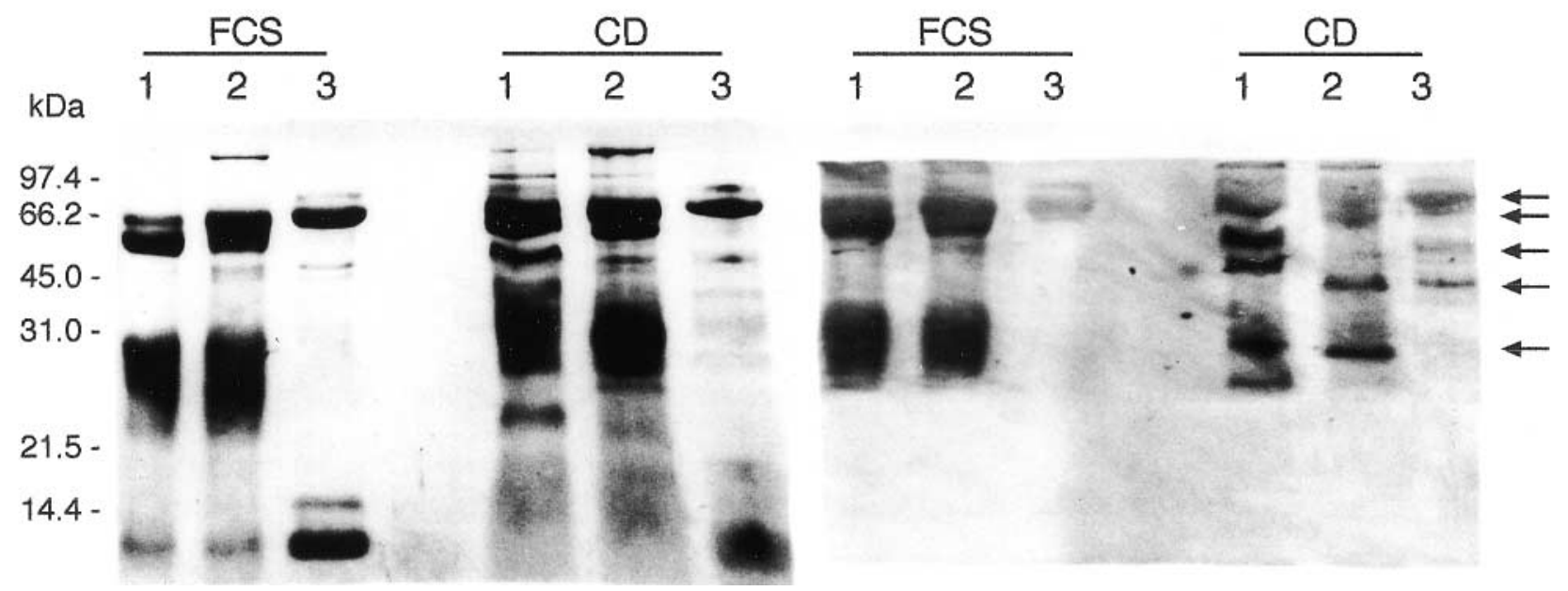

Fig. 1. SDS-PAGE (a) and blotting analysis (b) of proteins secreted by H. pylori in BBFCS or BBCD and precipitated by different ammonium sulphate saturations. Lane $1,0-40 \% ; 2,40-60 \% ; 3,60-80 \%$. Right margin arrows indicate the presence of the HSBP.

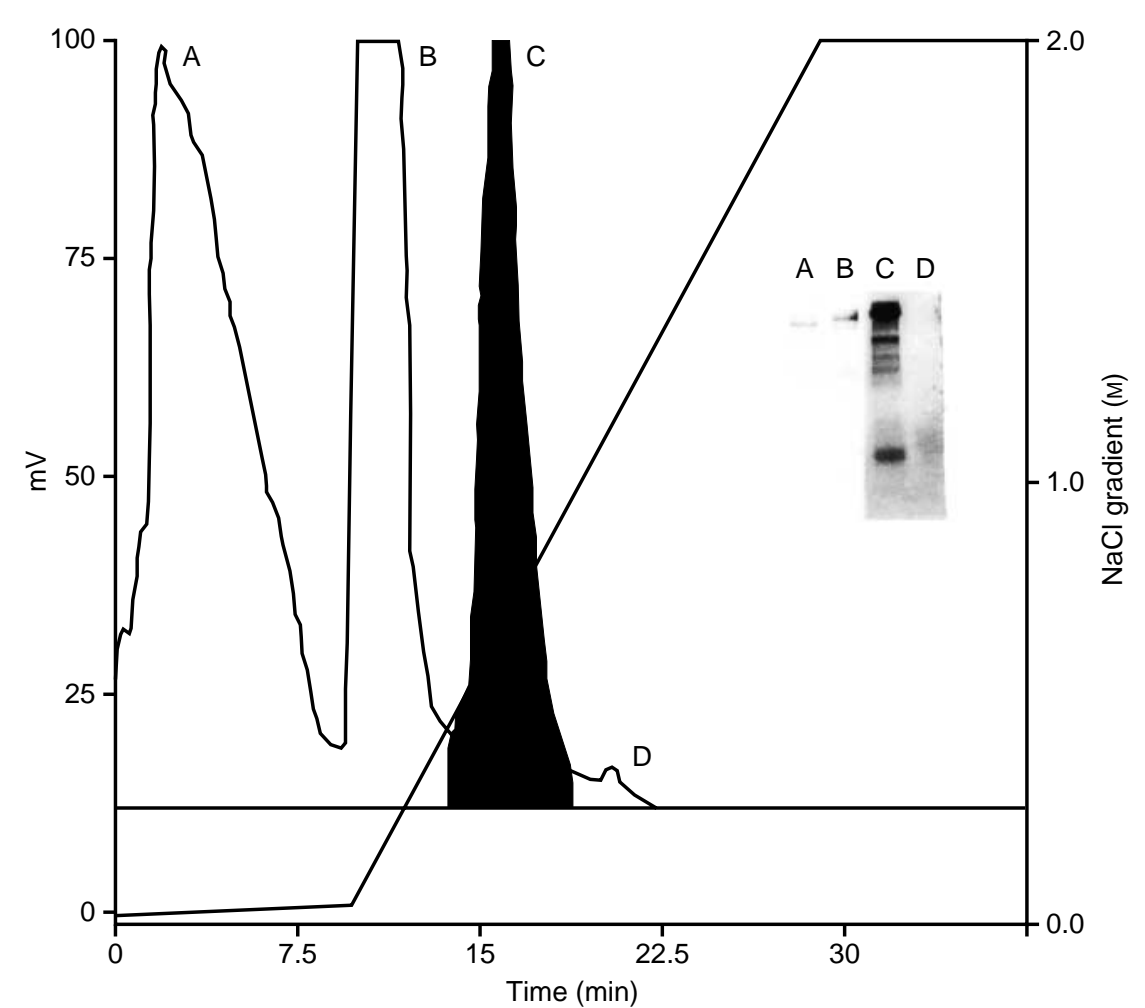

Fig. 2. Affinity chromatogram of HSBP from a $60-80 \%$ fraction of a BBCD culture on a 5-ml Heparin Hi-Trap column (flow rate, $1 \mathrm{ml} / \mathrm{min}$ ). Shaded region denotes HS-binding activity as shown by inhibition of ${ }^{125} \mathrm{I}-\mathrm{HS}$ binding to $H$. pylori cells (unpublished data). Insert: SDS-PAGE of fractions collected from the column.

column (LKB-Pharmacia, Uppsala, Sweden) in different elution conditions revealed that all the HSBPs copurified in the same fraction (Fig. 2, shaded zone), where the 71.5-, 66.2- and 54.4-kDa protein bands were detected, correlating with the electrophoretic profile of the $60-80 \%$ ammonium sulphate precipitation that was put on the chromatographic column.

\section{Cell-associated HSBP}

Proteins obtained from the bacterial cell surface by distilled water and $3 \mathrm{M}$ urea extraction of cells harvested from solid GAB-CAMP, BBFCS and BBCD cultures were analysed by SDS-PAGE and blotting analysis (Fig. 3a). Similar protein bands were observed in both extraction procedures, especially the $66.2-\mathrm{kDa}$ 
a

b

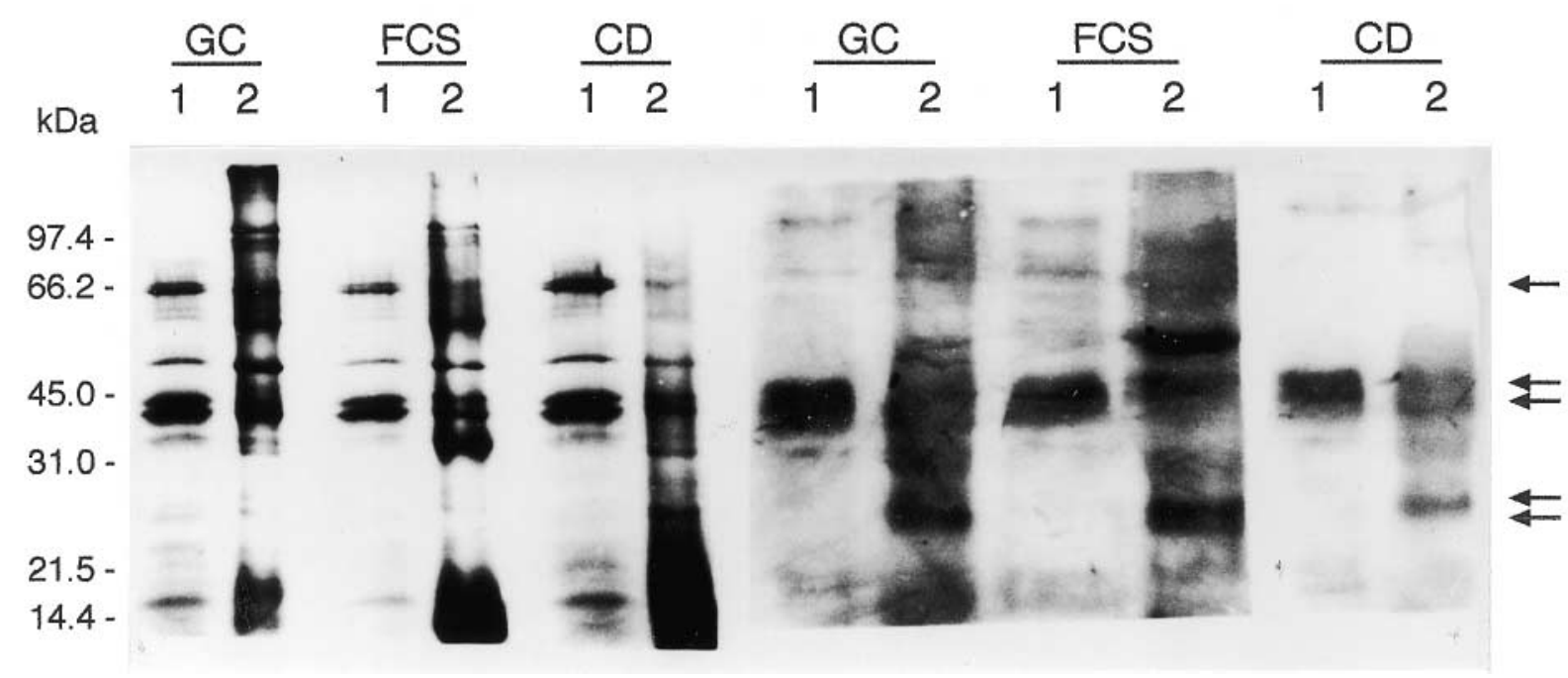

Fig. 3. SDS-PAGE (a) and blotting analysis (b) of (1) water and (2) $3 \mathrm{M}$ urea extracts from H. pylori cells grown on solid GAB-CAMP (GC) in BBFCS and in CD media. Right margin arrows indicate the presence of the HSBP.

protein. Also 53.0-, 44.3- and 40.1-kDa protein bands were present in both extracts.

Blotting analysis revealed that the 66.2-, 44.3- and 40.1-kDa proteins exhibited POD-HS affinity (Fig. 3b). Nevertheless, in the distilled water extract, the 44.3and $40.1-\mathrm{kDa}$ HSBP bands were the predominant proteins, whereas in the urea extract a $23.8-\mathrm{kDa}$ HSBP was predominant.

\section{OMP HSBP}

SDS-PAGE and blotting analysis of the OMP fractions of $H$. pylori cells cultured on GAB-CAMP medium or in BBFCS and BBCD revealed the presence of a large number (seven proteins) of HSBPs (Fig. 4). In this cell compartment, the 66.2-kDa HSBP was also evident in all the extracts, but the predominant protein band was detected at $47.2 \mathrm{kDa}$, also with HS-POD affinity.

Minor protein bands at 51.2, 44.3, 34.2, 20.4 and $29.8 \mathrm{kDa}$ with affinity for POD-HS were also present in the three bacterial OMP preparations. Although the starting concentration of bacterial cells was $10^{6}$ cells $/ \mathrm{ml}$, some difference in the protein proportion was observed among the extracts, mainly in the BBCD harvest, where low molecular mass proteins were detected at 30.4 and $29.8 \mathrm{kDa}$, both of which had enhanced HS-POD affinity.

\section{Iso-electric focusing}

Electrofocusing of the $60-80 \%$ ammonium sulphate protein fraction from $\mathrm{BBCD}$ culture showed that most a

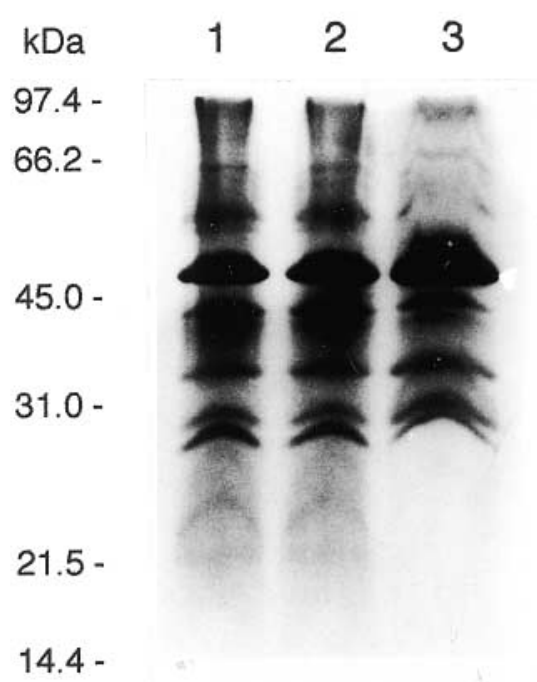

b
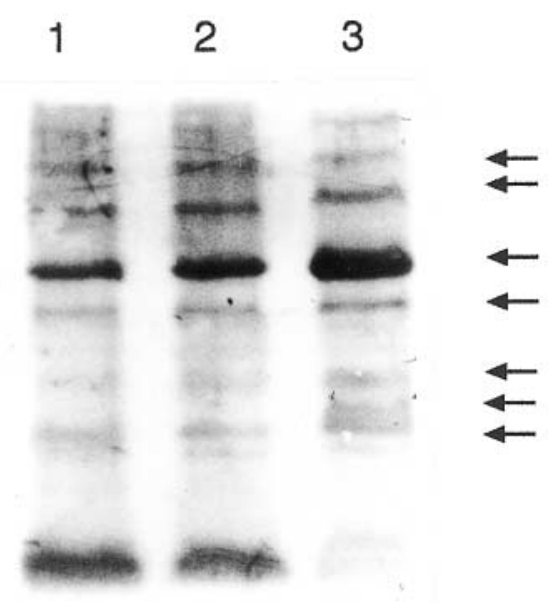

Fig. 4. SDS-PAGE (a) and blotting analysis (b) of OMPs extracted from $H$. pylori cells grown in three culture media. Lane 1, GAB-CAMP medium; 2, BBFCS 3, BBCD. Right margin arrows indicate the presence of the HSBP. 
of the proteins focused at $\mathrm{pH} 4-6$ (Fig. 5A). Blotting analysis revealed two main protein bands with HSbinding activity at pI 5.4 and 5.0, and a weaker band with a pI of 5.2 (Fig. 5B).

To determine the correspondence between the molecular mass data and the pI measurements, electrophoresed proteins were cut out of the SDS-polyacrylamide gel with a stained gel as reference, and the protein was eluted from the gel. The eluted proteins were then loaded on to an iso-electric focusing gel. The results indicated that the $66.2-\mathrm{kDa}$ protein had a $\mathrm{pI}$ of 5.4 and the $71.5-\mathrm{kDa}$ protein had a $\mathrm{pI}$ of 5.0.

\section{$\mathrm{NH}_{2}$-terminal amino acid sequence}

On the basis of previous studies [28], in which high molecular mass proteins showed the highest affinity for HS, two HSBPs (71.5 and $66.2 \mathrm{kDa}$ ) from the $60-80 \%$ fraction obtained from BBCD culture (Fig. 1) were analysed by amino acid sequencing. One HSBP band was designated as HSBP54 (molecular mass $66.2 \mathrm{kDa}$, pI 5.4) and the second HSBP band was designated as HSBP50 (molecular mass $71.5 \mathrm{kDa}$, pI 5.0). Amino acid sequencing of these two proteins after 10 cycles (10 amino acids) provided the sequence information shown in Table 1. The major OMP-HSBP was also sequenced; however, the protein was first hydrolysed with trypsin and a major internal polypeptide fragment was subjected to Edman degradation and $\mathrm{NH}_{2}$-terminal amino acid sequencing (Table 1).

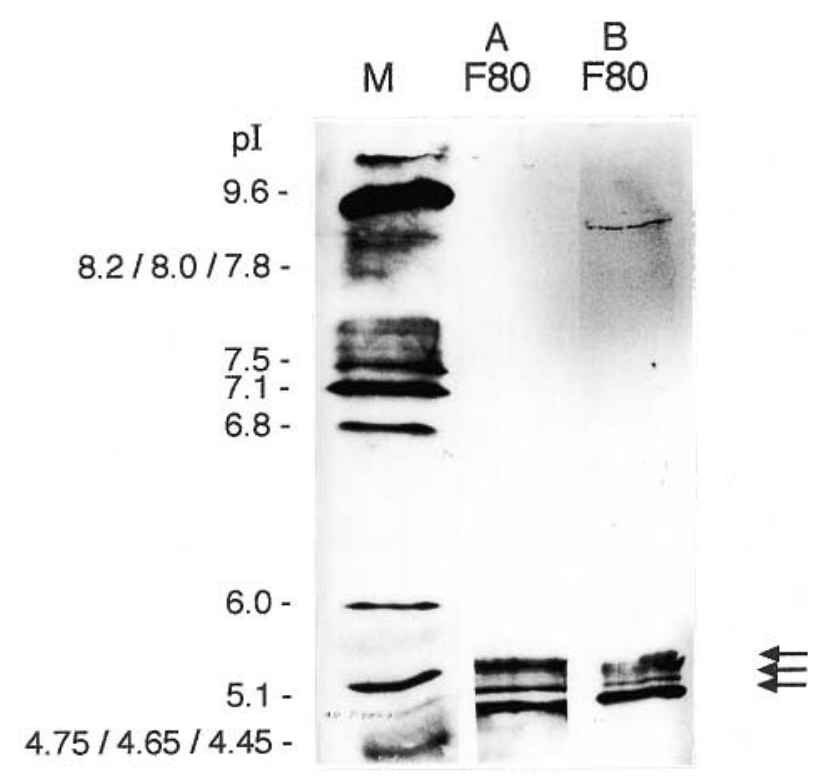

Fig. 5. Iso-electric focusing (IEF) of proteins secreted by H. pylori in BBCD precipitated by $60-80 \%$ (F80) ammonium sulphate saturation. (A) IEF, (B) blotting analysis. Right margin arrows indicate the presence of the HSBP; M, marker.
Table 1. Amino acid sequences of three $H$. pylori HSBPs

\begin{tabular}{ll}
\hline HSBP label & Sequence* $^{*}$ \\
\hline HSBP50 $^{\dagger}$ & V-P-E-R-A-V-R-A-H-T- \\
HSBP54 $^{\dagger}$ & V-H-L-P-A-D-K-T-N-V- \\
OMP-HSBP $^{*}$ & -Q-V-I-T-Y-V-E-G-K-W- \\
\hline
\end{tabular}

* The single-letter amino acid code is used.

†Amino-terminal sequence.

IInternal sequence.

\section{Discussion}

It is important to establish the conditions that make the adherence and, therefore, the colonisation of the gut mucosal surfaces by bacteria possible. Several candidate receptors for attachment of $H$. pylori to target cells have been proposed, including sulphogalactosylceramide $[39,40]$, and extracellular matrix (ECM) proteins $[10,22,41]$. Futhermore, Slomiany et al. demonstrated that there is specificity of the bacterium for lactosylceramide sulphate and $\mathrm{GM}_{3}$ gangliosides [42]. Borén et al. reported that soluble glycoproteins that possessed the $\mathrm{Le}^{\mathrm{b}}$ antigen inhibited bacterial adhesion in situ. It has also been found that $H$. pylori has strong binding affinity for HS proteoglycan [12]. Some of the adhesive molecules from $H$. pylori responsible for binding to host receptors have been isolated and characterised [12, 43, 44].

Kamisago et al. addressed the role of sulphatides in attachment of $H$. pylori to a gastric cancer cell line, KATO III, and found that the adhesion process can be significantly inhibited by heparin [40]. Based on the assumption that $H$. pylori has adhesive molecules that enable the bacterium to interact with host-sulphated glycoconjugates as an important step during the adhesion and colonisation process, the present study isolated and characterised a group of extracellular, cellassociated and OMP proteins from $H$. pylori with affinity for HS proteoglycan, which may enable the pathogen to target sulphated glycoconjugates exposed on mucosal epithelial cells.

Studies have shown the presence of HSBP in $H$. pylori $[18,19,28,45]$, where the interaction of these bacterial proteins with host components was exploited. It could be determined that these proteins recognised heparin, gastrointestinal cell surface HS, in an association inhibitable by the presence of sulphated carbohydrate polymers in the media. Furthermore, H. pylori HSBP were shown to interact with heparin-dependent growth factors, interfering with the tissue regeneration induced by these factors [19], and Chmiela et al. observed that the binding of different $H$. pylori strains to cell lines was decreased by pretreatment of bacterial cells with heparin [46].

Furthermore, recent work in this laboratory has shown that oral immunisation of $\mathrm{BALB} / \mathrm{c}$ mice with vaccine composed of $H$. pylori HSBP prevented bacterial 
colonisation of the gut mucosa by a mouse-adapted $H$. pylori strain, as evidenced by histopathological examination, culture, rapid urease test and PCR assays [47]. This vaccine administration resulted in a reduction of the adhesion of the bacteria to the gastrointestinal tract, from $100 \%$ in unvaccinated mice to $6.6 \%$ in the HSBPCTB-immunised group, providing additional evidence on the role that the $H$. pylori HSBP play in the disease development.

A chromatography procedure allowed the purification of a set of extracellular proteins, with different molecular masses, showing high reactivity towards POD-HS. However, these proteins appear to differ from the H. pylori heat-shock protein described above. For example, their $\mathrm{NH}_{2}$-terminal amino acid sequences do not have any homology with the $62-\mathrm{kDa}$ heat shock protein described by Evans et al. in H. pylori [35] and they do not react with mouse polyclonal antibodies which recognise the $62-\mathrm{kDa}$ heat-shock protein (data not shown).

The findings in the present study indicate that $H$. pylori yields mainly two extracellular proteins $(71.5 \mathrm{kDa}$, pI 5.0 and $66.2 \mathrm{kDa}, \mathrm{pI} 5.4$ ) and one OMP (45 kDa) that exhibit strong affinity for POD-HS proteoglycan, shown by blotting analysis. None of them show any similarity with a known heparin-related lectin. The $\mathrm{NH}_{2}$-terminal amino acid signature of these three HSBPs did not show homology either to other adhesins previously described in $H$. pylori, or to each other. An amino acid sequence analysis of the OMP with the BLAST-system protein bank revealed that this protein differs from that found in the extracellular space of $H$. pylori and from other bacterial HSBPs.

An interesting observation is that the $66.2-\mathrm{kDa}$ extracellular HSBP has a remarkable homology to the haemoglobin $\alpha$-chain, human tumour necrosis factor receptor-2 precursor and to an Escherichia coli chaperon protein. However, when equine haemoglobin was used for inhibition experiments of binding of HS by $H$. pylori cells, or binding of HS to HSBP immobilised on Immobilon-P membranes, no inhibitory activity was seen (data not shown).

To rule out the possibility that the extracellular HSBPs were heparin-binding proteins in the fetal calf serum used in the culture media, the study also evaluated whether the HSBPs were present in the serum-free broth media, and if the HSBPs were also associated with the bacterial cell. For this assessment, bacterial cells were grown in BBCD instead of BBFCS. SDSPAGE and blotting analysis showed the presence of HSBPs in the culture supernates of the serum-free broth media. Also, four proteins of molecular mass similar to those HSBPs from the culture supernates of BBFCS were detected in the urea extracts, which suggests that the HSBPs are associated with the bacterial cell.
The results of the present study may suggest that growth of $H$. pylori in broth media allows the secretion of the proteins into the culture medium, although this can also be caused by the absence of an anchored pedestal for these antigens $[4,12]$. The concentrations found in cell-associated proteins extracted from $H$. pylori cells grown in BBFCS and BBCD were similar on the basis of protein concentration obtained from the same bacterial mass (wet mass) and with the same extraction volumes. The presence of these HSBPs in $H$. pylori may suggest a potential vaccine candidate for the development of alternative immunoprophylactic strategies against $H$. pylori-associated gastritis and duodenal ulcers. Work is being carried out in this laboratory to elucidate the immunostimulant and immunoprotective properties of the extracelluar HSBPs.

This work was supported by the Center for Biological Research, CIBNOR (ABM-11). E.R-B. was the recipient of a scholarship from the Mexican Council of Science and Technology (CONACyT). We thank Dr Ellis Glazier for editing the English language text, Ariel Cruz-Villacorta for technical assistance and Aldo Vargas for photographic support.

\section{References}

1. Hazell SL, Lee A, Brady L, Hennessy W. Campylobacter pyloridis and gastritis: association with intracellular spaces and adaption to an environment of mucus as important factors in colonization of the gastric epithelium. J Infect Dis 1986; 153: $658-663$.

2. Petersen WL. Helicobacter pylori and peptic ulcer disease. $N$ Engl J Med 1991; 324: 1043-1048.

3. Lee A, Fox J, Hazell S. Pathogenicity of Helicobacter pylori: a perspective. Infect Immun 1993; 61: 1601-1610.

4. Borén T, Falk P, Roth KA, Larson G, Normark S. Attachment of Helicobacter pylori to human gastric epithelium mediated by blood group antigens. Science 1993; 262: 1892-1895.

5. Clyne M, Drumm B. Adherence of Helicobacter pylori to primary human gastrointestinal cells. Infect Immun 1993; 61: 4051-4057.

6. Buck GE. Campylobacter pylori and gastroduodenal disease. Clin Microbiol Rev 1990; 3: 1-12.

7. Eaton KA, Krakowka S. Effect of gastric $\mathrm{pH}$ on ureasedependent colonization of gnotobiotic piglets by Helicobacter pylori. Infect Immun 1994; 62: 3604-3607.

8. Ghiara P, Marchetti M, Blaser MJ et al. Role of the Helicobacter pylori virulence factors vacuolating cytotoxin, $\mathrm{CagA}$, and urease in a mouse model of disease. Infect Immun 1995; 63: 4154-4160.

9. Eaton KA, Brooks CL, Morgan DR, Krakowka S. Essential role of urease in pathogenesis of gastritis induced by Helicobacter pylori in gnotobiotic piglets. Infect Immun 1991; 59: 2470-2475.

10. Trust TJ, Doig P, Emödy L, Kienle Z, Wadström T, O'Toole P. High-affinity binding of the basement membrane proteins collagen type IV and laminin to the gastric pathogen Helicobacter pylori. Infect Immun 1991; 59: 4398-4404.

11. Tsuda M, Karita M, Morshed MG, Okita K, Nakazawa T. A urease-negative mutant of Helicobacter pylori constructed by allelic exchange mutagenesis lacks the ability to colonize the nude mouse stomach. Infect Immun 1994; 62: 3586-3589.

12. Borén T, Normark S, Falk P. Helicobacter pylori: molecular basis for host recognition and bacterial adherence. Trends Microbiol 1994; 2: 221-228.

13. Blaser MJ. Helicobacter pylori and the pathogenesis of gastroduodenal inflammation. J Infect Dis 1990; 161: 626-633.

14. Blaser MJ. Hypotheses on the pathogenesis and natural history of Helicobacter pylori-induced inflammation. Gastroenterology 1992; 102: 720-727.

15. Drazek ES, Dubois A, Holmes RK et al. Cloning and 
characterization of hemolytic genes from Helicobacter pylori. Infect Immun 1995; 63: 4345-4349.

16. Manetti R, Massari P, Burroni D et al. Helicobacter pylori cytotoxin: importance of native conformation for induction of neutralizing antibodies. Infect Immun 1995; 63: 4476-4480.

17. Taylor DN, Blaser MJ. The epidemiology of Helicobacter pylori infection. Epidemiol Rev 1991; 13: 42-59.

18. Ascencio F, Fransson LA, Wadström T. Affinity of the gastric pathogen Helicobacter pylori for the N-sulphated glycosaminoglycan heparan sulphate. J Med Microbiol 1993; 38: $240-244$.

19. Ascencio F, Hansson HA, Larm O, Wadström T. Helicobacter pylori interacts with heparin and heparin-dependent growth factors. FEMS Immunol Med Microbiol 1995; 12: 265-272.

20. Lindahl U, Lidholt K, Spillmann D, Kjellén L. More to "heparin" than anticoagulation. Thrombosis Res 1994; 75 $1-32$.

21. Oksala O, Salo T, Tammi R et al. Expression of proteoglycans and hyaluronan during wound healing. J Histochem Cytochem 1995; 43: $125-135$.

22. Valkonen KH, Wadström T, Moran AP. Interaction of lipopolysaccharides of Helicobacter pylori with basement membrane protein laminin. Infect Immun 1994; 62:3640-3648.

23. Frevert U, Sinnis P, Cerami C, Shreffler W, Takacs B, Nussenzweig V. Malaria circumsporozoite protein binds to heparan sulphate proteoglycans associated with the surface membrane of hepatocytes. J Exp Med 1993; 177: 1287-1298.

24. Love DC, Esko JD, Mosser DM. A heparin-binding activity on Leishmania amastigotes which mediates adhesion to cellular proteoglycans. J Cell Biol 1993; 123: 759-766.

25. Noel GJ, Love DC, Mosser DM. High-molecular-weight proteins of nontypeable Haemophilus influenzae mediate bacterial adhesion to cellular proteoglycans. Infect Immun 1994; 62: 4028-4033.

26. Patti JM, Allen BL, McGavin MJ, Höök M. MSCRAMMmediated adherence of microorganisms to host tissues. Annu Rev Microbiol 1994; 48: 585-617.

27. Doig P, Austin JW, Kostrzynska M, Trust TJ. Production of a conserved adhesin by the human gastroduodenal pathogen Helicobacter pylori. J Bacteriol 1992; 174: 2539-2547.

28. Utt M, Wadström T. Identification of heparan sulphate binding surface proteins of Helicobacter pylori: inhibition of heparan sulphate binding with sulphated carbohydrate polymers. $J \mathrm{Med}$ Microbiol 1997; 46: 541-546.

29. Morgan DR, Freedman R, Depew CE, Kraft WG. Growth of Campylobacter pylori in liquid media. J Clin Microbiol 1987; 25: $2123-2125$

30. Shahamat M, Mai UE, Pasko-Kolva C, Yamamoto H, Colwell RR. Evaluation of liquid media for growth of Helicobacter pylori. J Clin Microbiol 1991; 29: 2835-2837.

31. Ansorg R, Von Recklinghausen RG, Pomarius R, Schmid EN Evaluation of techniques for isolation, subcultivation, and preservation of Helicobacter pylori. J Clin Microbiol 1991; 29: $51-53$.
32. Kehler EG, Midkiff BR, Westblom TU. Evaluation of three commercially available blood culture systems for cultivation of Helicobacter pylori. J Clin Microbiol 1994; 32: 1597-1598.

33. Olivieri R, Bugnoli M, Armellini D et al. Growth of Helicobacter pylori in media containing cyclodextrins. J Clin Microbiol 1993; 31: 160-162.

34. Drumm B, Sherman P. Long-term storage of Campylobacter pylori. J Clin Microbiol 1989; 27: 1655-1656.

35. Evans DJ, Evans DG, Engstrandt L, Graham DY. Ureaseassociated heat shock protein of Helicobacter pylori. Infect Immun 1992; 60: 2125-2127.

36. Derclaye I, Delor I, Van Bouchaute M, Moureau P, Wauters G, Cornelis GR. Identification of Campylobacter jejuni and $C$. coli by gel electrophoresis of the outer membrane proteins. $J$ Clin Microbiol 1989; 27: 1072-1076.

37. Doig P, Trust TJ. Identification of surface-exposed outer membrane antigens of Helicobacter pylori. Infect Immun 1994; 62: 4526-4533.

38. Laemmli UK. Cleavage of structural proteins during the assembly of the head of bacteriophage T4. Nature 1970; 227: $680-685$

39. Saitoh T, Sugano K, Natomi H et al. Glycosphingolipid receptors in human gastric mucosa for Helicobacter pylori. Eur J Gastroenterol Hepatol 1992; 4 Suppl 1: S49-S53.

40. Kamisago S, Iwamori M, Tai T, Mitamura K, Yazaki Y, Sugano K. Role of sulfatides in adhesion of Helicobacter pylori to gastric cancer cells. Infect Immun 1996; 64: 624-628.

41. Ringnér M, Paulsson M, Wadström T. Vitronectin binding by Helicobacter pylori. FEMS Microbiol Immunol 1992; 105: 211-224

42. Slomiany BL, Piotrowski J, Samanta A, VanHorn K, Murty VLN, Slomiany A. Campylobacter pylori colonization factor shows specificity for lactosylceramide sulphate and $\mathrm{GM}_{3}$ ganglioside. Biochem Int 1989; 19: 929-936.

43. Lingwood CA, Wasfy G, Han H, Huesca M. Receptor affinity purification of a lipid-binding adhesin from Helicobacter pylori. Infect Immun 1993; 61: 2474-2478.

44. O'Toole PW, Janzon L, Doig P, Huang I, Kostrzynska M, Trust TJ. The putative neuraminyllactose-binding hemagglutinin HpaA of Helicobacter pylori CCUG 17874 is a lipoprotein. J Bacteriol 1995; 177: 6049-6057.

45. Ljung A, Moran AP, Wadström $\mathrm{T}$. Interactions of bacterial adhesins with extracellular matrix and plasma proteins: pathogenic implications and therapeutic possibilities. FEMS Immunol Med Microbiol 1996; 16: 117-126.

46. Chmiela M, Lawnik M, Czkwianianc E et al. Attachment of Helicobacter pylori strains to human epithelial cells. J Physiol Pharmacol 1997; 48: 393-404.

47. Ruiz-Bustos E, Sierra-Beltran A, Romero MJ, RodriguezJaramillo C, Ascencio F. Protection of BALB/c mice against experimental Helicobacter pylori infection by oral immunisation with $H$. pylori heparan sulphate-binding proteins coupled to cholera toxin $\beta$-subunit. $J$ Med Microbiol 2000; 49: $535-541$. 